\title{
Adult Systemic Anaplastic Large Cell Lymphoma
}

National Cancer Institute

\section{Source}

National Cancer Institute. Adult Systemic Anaplastic Large Cell Lymphoma. NCI

Thesaurus. Code C27366.

An anaplastic large cell lymphoma affecting multiple anatomic sites and occurring in adults. 